\title{
Unmasking Juridical Humanity
}

\author{
Nimer Sultany
}

\begin{abstract}
A review of Samera Esmeir, Juridical Humanity: A Colonial History (Stanford University Press, 2012), 384 pp, ISBN: 978-0804783149.
\end{abstract}

This is an outstanding book. It is a multi-disciplinary tour de force inquiry into the role of the law in society. It is descriptively thick, methodologically rich, stylistically clear and gripping, critical in its outlook, and normatively attractive. Taking the British colonial occupation of Egypt as her case study, Samera Esmeir shows how the law was implicated in producing the 'human' and constructing 'humane' practices. Through a genealogy of the colonial career of the construction of the 'human', Esmeir convincingly argues that the production of the 'human' was intertwined with violence, discipline and dispossession. For that purpose Esmeir assembles an impressive range of historical data, which she analyses through the lens of sophisticated theoretical tools. The book's rigour is exemplified by the fact that Esmeir rarely, if ever, cites a theoretician without compellingly criticising his or her theory.

This essay offers one possible reading — my reading — of this rich book. Parts I and II summarise the book's main arguments. Part I presents the descriptive background to the concept of 'juridical humanity'. Part II shows how the book challenges both liberal and anti-colonial accounts of law since they both presuppose 'juridical humanity'. Parts III and IV situate the book within critical traditions and critically examine some of its primary themes.

\section{WHAT IS JURIDICAL HUMANITY?}

According to the liberal fairy tale, the rule of law-even under colonialism-is associated with progress, modernisation, and the protection of human rights. In Egypt's case, the British and some Egyptian legal scholars distinguished between the lawless, pre-colonial 
khedive's rule and the rule of law under the British occupation. The former was characterised by the violent, arbitrary whim of the 'rule of men', while the latter prided itself on the imposition of impersonal, general, abstract rules. The former imposed inhumane punishment, while the latter's punishment was humane. Refuting these characterisations, Esmeir problematises the distinction between colonial and pre-colonial law. The fairy tale is challenged by historical evidence which shows that the khedive's rule was not as arbitrary and lawless as the British and some scholars claimed; that some cruel punishments had been cancelled before the British occupation; and that sharia law under the khedive had been developed into a body of rules. It is also challenged by the fact that some cruel punishments persisted under British rule, and that zones of lawlessness persisted under colonial law in the private estates. Colonial law did not abolish violence; it merely re-drew the lines of legally prescribed violence. The difference between colonial and pre-colonial law, then, is not between the humane and inhumane, but rather between modes of inflicting suffering.

Furthermore, law can be seen as a story of progress only if one ignores the role of law in the advancement of the interests of the colonial rulers of Egypt. Unlike orthodox Marxist accounts that marginalise the role of law, Esmeir insists on the constitutive role of the law. ${ }^{1}$ The 'human' and 'humane' were not mere cynical rhetorical gestures or ideological masks $(90,114)$. Unlike some liberal accounts of the law as an autonomous domain providing an apolitical background for social interaction, Esmeir scrutinises the politics of the law and its effects in the colonial context. For Esmeir, the law contributed to the colonisation of Egypt through the very construction of the 'human'. This construction was part and parcel of political, criminal and economic institutions and practices that were integral to the colonial occupation. It was a disciplinary power that not only justified colonial rule but also made it possible by moulding the Egyptians as subjects. 'Juridical humanity' is the term that Esmeir coins to describe this power and the practices of constituting the 'human' via law. ${ }^{2}$ For 'juridical humanity', the 'human' is simultaneously the law's end and its grounds for violence and the infliction of pain on colonised subjects. Pain is defined - according to a definition of the 'human'—and deployed for the sake of the 'human' (147). Juridical humanity is essentially a utilitarian

1 Many Marxist writers rejected this orthodox approach and developed accounts of the role of law that reject both the instrumentalist view and the autonomy of law. See eg Isaac D Balbus, 'Commodity Form and Legal Form: An Essay on the "Relative Autonomy” of the Law' (1977) 11 Law \& Society Review 571. Nevertheless, see a discussion of 'the problem of law as constitutive' for Marxist analysis of the law in Mark V Tushnet, 'Marxism as Metaphor' (1983) 68 Cornell Law Review 281, 281, 285-7 (reviewing H Collins, Marxism and Law (Clarendon Press, 1982)).

2 In this sense the subject matter of the book is not well-meaning humanitarian efforts that may have negative implications. See David Kennedy, The Dark Sides of Virtue: Reassessing International Humanitarianism (Princeton University Press, 2005). Nor is the subject matter of the book the ways in which international law moves from a state-centred approach to one that centralises humanity (ie the interests of persons and groups of persons). See Ruti Teitel, Humanity's Law (Oxford University Press, 2011). 
concept in which pain or suffering is regulated and manipulated (111) for the sake of abolishing excessive suffering, disproportional violence and unproductive cruelty.

Juridical humanity deploys a specific mode of legal consciousness; a particular approach to-and understanding of - the law. Esmeir reads the work of Egyptian textbook writers in order to portray this consciousness, which presented legal reform as a break with the past and sought to erase the authoritative power of the pre-colonial tradition. This account helps Esmeir present a nuanced view of the reforms: unlike those who argue that the reforms were a colonial imposition, Esmeir shows that Egyptian legal elites_-as evidenced by the textbook genre-supported this reform. Unlike those who argue that the reforms were solely an outcome of internal demands either to resist the British or to imitate European ideals, Esmeir shows that rising Egyptian legal elites endorsed the reforms because doing so allowed them to replace the declining pre-colonial legal elites. ${ }^{3}$

In order to illustrate this project of legally prescribed humanisation via the regulation of suffering in colonial Egypt, Esmeir focuses on law's attitude to peasants, labourers, prisoners, rebels, bandits, animals and insects. Esmeir recounts in elaborate detail how colonial officials sought through legal reforms and legal enactments to treat peasants, labourers, prisoners, bandits and rebels in a 'humane' way. She also shows that this humanity is reflected in the penalisation of certain practices towards animals and insects and in the sanctioning of other practices. In all of these, colonial officials sought, on the one hand, to distinguish between their rule and pre-colonial rule, and, on the other, to govern Egypt and advance their interests.

The British declared the abolition of forced labour, which was one of the allegedly inhumane practices of pre-colonial rule. Nonetheless, colonial law allowed state-mandated forced labour in cases of plagues or Nile floods. Thus, an inhumane practice persisted under colonial rule given state interests. Additionally, while colonial law freed labour, it refrained from intervening in cruelty and violence against labourers in private estates. It thus created a bifurcated system of public freedom and private unfreedom. For instance, the ban on corporal punishment using the whip applied only to state officials. Hence the inhumane practice persisted in the domain of private property. The law's role was not merely one of passive non-intervention. In the first place, state law was implicated in the production of the labourers' class. Land confiscation, land tax, and the sanctioning of moneylending transactions - including a state-established bank-led to the loss of land and the transformation of peasants and small landowners into labourers $(154,162-3,212,216)$. Moreover, the state itself sold its lands to wealthy private owners

3 In this sense Esmeir's argument is analogous to Saba Mahmood's argument—albeit based in the more recent history of Egypt and in the context of women's role in religious revival-that agency is not equal to resistance. For Esmeir, one can recognise Egyptian agency without inferring from it an Egyptian resistance to, and rejection of, British reforms. For Mahmood, one can recognise religious women's agency even though that did not translate into a resistance to, and rejection of, patriarchy. Saba Mahmood, Politics of Piety: The Islamic Revival and the Feminist Subject (Princeton University Press, 2005). 
(211). Thus, state law transferred its responsibility for the fate of these labourers to the estate owners and their managers. In the Legal Realist Morris Cohen's words, the state delegated its sovereignty to the owners of private property. ${ }^{4}$ Esmeir collapses the public/ private distinction: ${ }^{5}$ private estates were endowed with public regulatory powers. Private power was indebted to state law's lack of intervention, and state law was indebted to private regulation and ordering, which relieved it of the need to supervise and discipline labourers on the estates (225). Colonial law is thus implicated in the exploitation, and the dreadful working conditions, of these labourers. Esmeir recovers evidence for the abuse of labourers and their abandonment by state law through murder investigations in which labourers killed their managers. These conditions show that private estates were zones of lawlessness under the rule of law. They further show that the law's silence facilitated vengeance, which became a form of dispute resolution in the absence of estate courts (234). It thus seems that the rule of law produced suffering at the same time as it claimed to reduce suffering (239).

Prison reforms sought to introduce humane treatment of prisoners by preventing excessive suffering; but their focus was on the prisoner's body and biological life. Similarly, the British rejected the execution of the leaders of the Urabi rebellion and considered exile to be a humane punishment. The rebels were thus expelled from the political community and the state cared only for their biological life and physical needs. Exile was also the preferred humane punishment of bandits. Thus, in these three casesprisoners, rebels and bandits - the state reduced the moral agent to an animal-like condition (ie reduced to a body) at the very time it claimed to humanise him.

On the other hand, colonial criminal law sought to humanise and discipline Egyptians through regulating their treatment of animals by penalising inhumane practices. However, other modes of violence and cruelty against animals-like vivisection-were legally permitted. Some were even coerced by law as an act of humanisation through freedom from - and mastery over-nature. Colonial law identified cotton worms as an enemy that threatened the cotton industry, which was crucial to the British Empire's position in the global economy and to Egypt's ability to repay its debts. Hence it forced the peasants-including children - to manually destroy these insects and prosecuted those who did not remove them. It also forced peasants to destroy some plants-okra and hemp - that were a breeding ground for cotton worms, and were less profitable than cotton.

The effect of these measures was to conceal coercion. Formally, colonial law freed labour by abolishing forced labour, but it sanctioned it within private property and through criminalisation (190). Formally, it humanised the Egyptians, but effectively it harboured the very inhumane aspects it claimed to reject.

Morris Raphael Cohen, Law and the Social Order: Essays in Legal Philosophy (Harcourt Brace, 1933).

5 Collapsing a distinction does not imply sameness. It only means that the difference between A and B is one of degree rather than kind, because elements of A are found in B and elements of B are found in A. 


\section{THE VIOLENCE OF INCLUSION}

Esmeir challenges the liberal discursive move defending the rule of law. According to this move, one should distinguish between the ideal of the rule of law and abuses of this ideal by human actors such as colonial officials in Egypt. However, colonial officials understood themselves as advancing the rule of law and as humane. They did not necessarily think they were abusing the rule of law or deliberately violating it. Rather, the hybrid distinction between the ideal and the factual itself facilitated colonial rule (243). It allowed the justificatory apparatus that distanced the rule of law from unsavoury practices, whether by conceiving of them as exceptional measures (martial law, military tribunals and special commissions) or by attributing them to Egyptian misconduct. The colonial division of labour between the British and the Egyptian government allowed the British to both criticise the Egyptians for failing to ensure that their practices attained the ideals of rule of law and present excessive British practices as exceptional responses to the Egyptians' failure to maintain order. Therefore, excessive measures were not understood or presented as a violation of the ideal but rather as an attempt to restore and defend the ideal. The law unleashed its violence in the name of the ideal, and the ideal in return justified the law's violence. Juridical humanity, then, cannot be separated from both the ideal and violence $(282-3,287)$.

In this light, Esmeir's arguments expose many of the anti-colonial criticisms of liberal law as simplistic and insufficient. The problem is not, as some critics have argued, the suspension of the law in a 'state of exception'. Rather, it is the presence of law and the kind of arrangements it sought to advance. Some critics have argued that colonial law dehumanised the colonised by excluding them from the law's protection. However, Esmeir's book convincingly shows that colonial law sought to humanise the Egyptians by imposing on them certain definitions of what is humane. Colonial practices cannot merely be described as the legal exclusion of natives; rather it is often the inclusion in the law that led to their dispossession and disenfranchisement. Humanisation itself can be just as colonial or harmful to natives as dehumanisation. More importantly, this form of anti-colonial argument merely reproduces the paradigm that underpins the colonial perception. According to this paradigm, the law humanises and its absence dehumanises. The difference between colonial law and its critics becomes merely the question of which law humanises and which does not. In this way, the juridical is inscribed into the human and becomes her defining attribute. Without her endowment with rights, the human ceases to be human.

But there is no reason to see the human as a juridical construct whose humanity the law giveth or taketh away. If one understands the disciplinary power that the law unleashes on its subjects by constructing the human, one also sees the relationship of bondage that the law imposes on the very subjects it constructs. This bondage is politically and normatively objectionable. Politically it limits human potentialities and freedom by binding the human to the law and the state that constantly threatens to 
dehumanise. Normatively, defining the human in juridical ways obscures and marginalises alternative ways of conceiving of the human. The law's monopoly on defining the human means no less than the 'loss of the human to modern law' (5). One is able to think of alternative ways of conceiving of the 'human' because, notwithstanding modern law's monopoly, Egypt's history contains some traces of a non-juridical human and hence the loss is incomplete. Esmeir uncovers mystical Sufi voices that indicate the possibility of a different understanding of the human and her relationship to history and nature. In addition, juridical humanity is troubling because violence seems inescapable. The law's violence highlights the need for non-violence (288). Esmeir sees her book as an attempt to open 'a space for rebellion and struggle' (17). She advocates a different kind of politics in which multiple versions of the human compete and the human is freed from the law's chains. Despite the law's claim to universality, the juridical human that modern law universalises is only one version of the possible 'humans' that individuals and communities can envisage. The law impoverishes our human conditions when it restricts our practices and imagination to one version of the human to which violence is so central.

Ultimately, Esmeir affirms the possibility of resistance despite the law's monopoly and violence. Since the law is man (and woman) made, juridical humanity is a selfinflicted incapacity that need not be binding. Clearly, the centrality of juridical humanity inhibits our ability to change it, but Esmeir's work directs us towards destabilising this centrality in order to undermine unfreedom and hierarchy and expose suffering, exploitation and dispossession.

As such, this book is an important contribution to the study of Egypt's legal history, to the study of colonialism, and to the examination of the role of law. In order to understand Esmeir's achievement, one needs to locate the book in the existing literature on Egypt. Esmeir's explication of colonial disciplinary powers further develops and complements Timothy Mitchell's canonical work on Egypt. ${ }^{6}$ Mitchell focuses on the notion of representation, in which the world is structured as if it were an exhibit or a museum. Accordingly, the British colonisers represented Egypt as an orderless space lacking structure. Thus, the colonial powers introduced reforms in the form of urban planning, the military, model villages and education. These reforms were diffuse and pervasive disciplinary techniques that sought to create spatial organisation, industrious bodies, and disciplined souls. In so doing they produced the effect of structure and simultaneously allowed hierarchy, control and surveillance. Mitchell writes:

Disciplinary power ... works not from the outside but from within, not at the level of an entire society but at the level of detail, and not by restricting individuals and their actions but by producing them ... Power relations do not simply confront this individual as a set of external orders and prohibitions. His or her very individuality, formed within such institutions, is already the product of those relations. ${ }^{7}$

6 Timothy Mitchell, Colonising Egypt (University of California Press, 1991).

7 Ibid, xi. 
Hence, far from being a story of progress, these nineteenth-century modernising reforms went hand in hand with colonising Egypt and dominating Egyptians.

Mitchell's book, however, does not discuss the role of the legal system. This might be explained by Mitchell's Foucauldian methodology in which the law is quite marginal and underdeveloped. Consequently, Mitchell's story remains incomplete. Esmeir's book, then, fills this gap by undertaking an elaborate examination of the law's crucial contribution to colonial disciplinary powers in Egypt. One cannot understand the nature of the new personhood that colonialism sought to produce without Esmeir's inquiry into the particular legal tools deployed for that purpose and into the formation of legal consciousness. In fact, without the role of the legal system it may be difficult to fathom the difference between the operation of disciplinary powers in Europe (Foucault) and their operation in the colony/Egypt (Mitchell). It is the role of the legal system in the colonies that best expresses the 'civilising' and 'humanising' aspect of domination in the colonies. As mentioned above, penal law sought not merely to discipline and normalise the Egyptians but also to make them behave in ways that were congenial to Britain's imperial economic standing through efficient and optimal extraction of resources in occupied territories (as in the example of cotton worms).

\section{LIBERATION OF NATURE AND INDETERMINACY}

Above all, Juridical Humanity is an exemplary piece of critical scholarship and an outstanding contribution to the legal left. Esmeir's book can be read as a contribution to the intellectual strand that conceives of freedom as a liberation of nature as opposed to liberation from nature. Although these strands are at times intertwined, Charles Taylor distinguishes between them and suggests that the former is characteristic of the left, whereas the latter has often served Fascist and Futurist orientations. ${ }^{8}$ Liberation of nature is a critique of the pretensions of autonomous subjectivity, regimented desire, political domination, alienation, capitalism, and bureaucratic power. It seeks empowerment by removing disempowering and disciplining practices and institutions. Liberation from nature, on the other hand, is the creative power to impose an artificial order without natural constraints. Juridical humanity violently imposes on human beings an arbitrary, manipulative, selective and artificial humanisation. It seeks to impose a 'human nature' on them. It originates in the conception of the human as a fabricator and master of the social and natural world. By unmasking juridical humanity and its dark side, Esmeir is implying a return to un-manipulated human nature. It is thus a critique of liberation from nature and a call for the liberation of nature.

8 Charles Taylor, 'Review, Logics of Disintegration' (July/August 1988) 170 New Left Review 110 (reviewing P Dews, Logics of Disintegration: Post-Structuralist Thought and the Claims of Critical Theory (Verso, 1987)). 
This call is evident in the emphasis on the constitutive role of the law as an integral part of juridical humanity. Through this emphasis Esmeir contributes to critical scholarship that addresses the constitutive role of law. An important contributor to this scholarship is Critical Legal Studies, which blurred the distinction between law and society and showed that they are 'inextricably mixed. ${ }^{9}$ For these scholars, law is constitutive of social relations and of our consciousness. ${ }^{10}$ But emphasising the constitutive role of the law can be risky if it is not accompanied by the notion of indeterminacy. Esmeir comes close to a totalising conception of modern law at the end of the book. On the one hand, she writes: 'Inscribed in the text of the law, the juridical human had no place to flee. The threat of dehumanization came into being' (285). On the other hand, she suggests that the difficulty of change originates in the limited possibility of critique given the fact that modern law itself provides us with critical tools. Modern law already contains the possibility of criticism (289). The law thus implies that it need not be transcended because law itself allows us to improve and modify our conditions. For Esmeir these critical tools are insufficient because humans are still chained to the law. The choices that the law offers are limited to exile rather than execution, to proportional violence rather than excessive suffering.

This totalising conception is reminiscent of Foucault's own 'totalising scheme,, ${ }^{11}$ which inspired the conceptualisation of juridical humanity as a disciplinary power and technology of rule. However, an emphasis on law's indeterminacy-as in the works of the Legal Realists and the Critical Legal Studies movement-might have tempered the totalising orientation. Esmeir recounts some of the British disagreements about the preferred legal arrangements, and the way their conceptions of the humane changed over time. This should direct us towards the potential indeterminacy of modern law in its interpretation and application. Esmeir's invocation of indeterminacy is limited, however. She attributes the 'contradictory formation' of the law to the split between the ideal and factual, the British and the Egyptian:

[L]aw's violence and exceptions came to be relegated to factuality and humanity to ideality. Both the law and the world were purified from their condition of hybridity and were split along these lines, thereby engendering a contradictory formation. The chapter follows the course of historical events that contributed to the making, collapse, and the recovery of this distinction, or the splitting of the world, facilitated by the splitting of the law. Different historical periods within the colonial era and their respective legal orders emerge as productive

9 Robert W Gordon, 'Critical Legal Histories' (1984) 36 Stanford Law Review 57, 102, 107.

10 Ibid, 109-13.

11 Duncan Kennedy, 'The Stakes of Law, or Hale and Foucault!' (1991) 15 Legal Studies Forum $327,353$. See also Edward W Said, 'Travelling Theory' in The World, the Text, and the Critic (Harvard University Press, 1983) 242-7 (referring to Foucault's 'theoretical overtotalization [of social reality]', and to his conception of power as 'overblown'); Elia Zuriek, 'Theoretical and Methodological Considerations for the Study of Palestinian Society' (2003) 23 Comparative Studies South Asia, Africa and the Middle East 3, 5-6 (summarising criticisms of Foucault's marginalisation of agency and resistance). 
of particular relationships between law's idealized humanity and factualized violent measures. The splitting of the law was parallel to a corresponding split between the British normative legal gaze and Egyptian factual operations of the law. British legal action inhabited the realized world of ideals, claimed the sphere of guidance, and positioned Egyptians under colonial normative gaze. Crucially, the idealized stance (a technique of purification) enabled the British to turn law's ideals of humanity into violent weapons aimed at protecting their purified ideals (a new technique of hybridization). The resort to exceptional measures enabled, in turn, purified ideals of humanity. (243, emphasis in original)

Indeterminacy in this account originates in the instability of the split and in the critical power of ideals (286). I find this account convincing but incomplete. The contradiction, according to Critical Legal Studies scholars, goes deeper and is more subversive. It is manifested in the ideals and principles themselves (even when they are not hybrid in Esmeir's sense, ie they are not contaminated with factuality). Furthermore, it is evident in the normal operation of the law and not only in those legal measures deemed exceptional to purify the ideal. One way to examine this contradiction is through judicial law-making that deploys these ideals. But the book rarely discusses this aspect of colonial rule. Such an examination would have strengthened the book's aforementioned attack on the liberal defence mechanism (attributing bad practices to the 'abuse of the rule of law' or mistakes in its application). It might have revealed that juridical humanity is not merely intertwined with violence and inseparable from the ideal; but also that it is itself contradictory and incoherent. The possibility of criticism, then, emerges not only because ideals are 'recruited to criticize the violence of the law' (286), but also because 'ideals of humanity' are themselves contradictory. These contradictions, and their potential critical power, may or may not carry subversive potentialities. Whether these subversions occur becomes a contextual inquiry. The possibility that subversions will be lacking is contingent on different factors, such as the reality of power relations and the willingness of legal agents to do the necessary work to destabilise determinate legal categories or to stabilise indeterminate ones. ${ }^{12}$ This is a different argument than the one the book suggests by seeking the answer in the form of modern law. The difference between these arguments is analogous to the difference between two kinds of ideology critique: 'form determination'-which regards ideological content as an inescapable effect of the very form of law-and 'concrete determination'-which finds ideological content in particular legal pronouncements that emerge given specific power relations and struggles. ${ }^{13}$

12 See Duncan Kennedy, 'Freedom and Constraint in Adjudication: A Critical Phenomenology' in Legal Reasoning: Collected Essays (Davies Group, 2008) 11.

13 Alan Hunt, 'The Ideology of Law: Advances and Problems in Recent Applications of the Concept of Ideology to the Analysis of Law' (1985) 19 Law \& Society Review 11, 23. 


\section{INDETERMINACY, COERCION, BONDAGE}

The potential indeterminacy is important because Esmeir seeks to generalise her thesis to non-colonial contexts (286) where indeterminacy might be more consequential. The relationship between law's humanity and bondage or disciplinary power is not necessarily fixed or preordained. Esmeir argues that 'a juridical human may never be an antistate rebel' (284). The possibility of resistance lies, then, outside the law and appears as a negation of juridical humanity. However, modern law is neither inherently 'progressive' nor inherently 'conservative'. That is, modern law is not inherently favourable to goals associated with either left-of-centre or right-of-centre political camps. It is not inherently status-quo-destabilising nor status-quo-affirming. It is likely to play the latter role in many contexts, perhaps especially in a colonial context. But 'likely' does not imply an inherent feature of the law.

It is insufficient to point out the coercive element of the law in order to escalate the argument towards the form of law. Coercion-ie unfreedom-is central to law, but not all coercion is violence. A coercive element is likely to exist in legal arrangements that influence social relations (as in the bargaining power of different social agents acting in these situations under the shadow of background legal rules ${ }^{14}$ ) and hence in conceptions of the human that underpin these arrangements. Additionally, even in the absence of state law (as in anarchist conceptions of the social order), social structures can be just as coercive, and a particular conception of the human might dominate. Thus, non-juridical conceptions of the human can be coercive or overwhelmingly dominant in ways that eradicate the plurality of human conceptions. They can also be violent (consider, for example, the practice of sacrificing young virgins to the gods). Like juridical humanity, then, non-juridical conceptions may be coercive, violent and monopolistic. It follows that coercion, violence and monopoly are not distinctive to law and may be troubling in other conceptualisations of the human.

We need to distinguish between differing non-juridical conceptions and assess particular conceptions as normatively desirable or objectionable. Admittedly, this will be a contested distinction and should admit a family of conceptions of the human without reducing it to one 'universal' conception. But it is insufficient to argue for 'openness' and 'plurality' (285) because some conceptions may be no less oppressive than the rejected juridical conception. Clearly, this openness and plurality is limited (few today would defend a conception of the human that required sacrificing young virgins). A legal left perspective cannot be satisfied by demanding openness, because openness may admit conceptions of the human that are inconsistent with the goals of the liberation of nature. The need to demarcate the acceptable limits of openness and plurality is inescapable. Esmeir's book provides us with a first remarkable step towards envisaging such a project by clarifying the conceptual field and illustrating the potential negative normative effects of juridical humanity. For that, Esmeir should be highly commended.

14 See Kennedy (n 11). 